\title{
C-band polymorphism in relation to fertility in boars
}

\author{
K Christensen ${ }^{1}$, JO Pedersen ${ }^{2}$ \\ 1 The Royal Veterinary and Agricultural University, \\ Division of Animal Genetics, Department of Animal Science and Animal Health, and \\ 2 The Federation of Danish Pig Producers \\ and Danish Slaughterhouses, Copenhagen, Denmark
}

(Proceedings of the 9th European Colloquium on Cytogenetics of Domestic Animals; Toulouse-Auzeville, 10-13 July 1990)

polymorphism / fertility / C-banding

\section{INTRODUCTION}

Nielsen (1969) has shown that there is a standard deviation of 0.5 piglets per litter between boars with 'normal' semen quality. Investigations by Gustavsson (1988) and many others have shown that litter size in swine is reduced when the animals are carriers of chromosome abnormalities. Therefore, it was decided to include chromosome investigations on some of the low-fertility boars in the study on boar fertility among boars with normal semen quality. No gross aberrations were found, but the first sample of low-fertility boars had a high frequency of $\mathrm{C}$ band polymorphism of the acrocentric chromosomes compared to earlier findings ( $c f$ Christensen and Smedegård, 1978, 1979). The findings rendered it necessary to include a control group, which was designated as the boars with the highest fertility.

\section{MATERIALS AND METHODS}

The fertility investigation included 98 boars of the Danish Duroc breed stationed at 3 AI centers. All boars had been approved for AI use and their semen was routinely collected. When the semen was distributed, a registration card followed and, just prior to the expected farrowing, a new card was sent to record the results. The registered data were: herd no, boar no, sow no, parity, date of mating, farrowing date, number of pigs born alive, number of stillborns, eventual culling or returning to heat.

Only boars with more than 12 litters were included in the investigation. The litter size was measured as the total number born. The boars were listed according to their average litter size, and from this list the boars with high and low fertility, 
respectively, were selected for the chromosome studies. The total number born is considered to be the best parameter for expressing boar fertility, whereas the number born alive is a better reflection of female fertility.

The chromosome study comprised 22 boars divided into 4 samples. Sample 1 consisted of 6 low-fertility boars, sample 2 had 5 high-fertility boars and the last samples 3 and 4 were added to expand the material of low- and high-fertility boars; see table I.

Table I. The distribution of chromosome centromere polymorphism in 22 Duroc boars.

\begin{tabular}{lclll}
\hline \multirow{2}{*}{$\begin{array}{c}\text { Boar } \\
\text { no }\end{array}$} & $\begin{array}{c}\text { Average } \\
\text { litter }\end{array}$ & \multicolumn{2}{c}{ Chromosome } & \multirow{2}{*}{ Sample } \\
\cline { 3 - 4 } & & no 16 & $n o 17$ & \\
\hline 5768 & 7.8 & $-/-$ & $++/-$ & 1 \\
5683 & 9.0 & $++/-$ & $-/-$ & 1 \\
5801 & 10.5 & $-/-$ & $++/-$ & 1 \\
5802 & 10.9 & $++/-$ & $+/-$ & 3 \\
5699 & 11.1 & $+/-$ & $-/-$ & 1 \\
5723 & 11.1 & $-/-$ & $+/-$ & 3 \\
5813 & 11.1 & $++/++$ & $+/-$ & 3 \\
5722 & 11.2 & $-/-$ & $++/-$ & 1 \\
5607 & 11.6 & $++/-$ & $-/-$ & 3 \\
5739 & 11.6 & $+/-$ & $++/++$ & 3 \\
Average litter & 11.61 & & & \\
5766 & 11.7 & $+/-$ & $++/-$ & 1 \\
5625 & 11.7 & $-/-$ & $-/-$ & 4 \\
5686 & 11.8 & $-/-$ & $-/-$ & 2 \\
5828 & 11.8 & $-/-$ & $-/-$ & 4 \\
5647 & 11.9 & $-/-$ & $-/-$ & 4 \\
5810 & 12.1 & $+/+$ & $-/-$ & 4 \\
5536 & 12.3 & $-/-$ & $+/-$ & 4 \\
5805 & 12.6 & $-/-$ & $-/-$ & 2 \\
5812 & 12.7 & $-/-$ & $-/-$ & 2 \\
5794 & 12.8 & $-/-$ & $+/-$ & 4 \\
5700 & 12.9 & $-/-$ & $++/-$ & 2 \\
5562 & 13.1 & $-/-$ & $-/-$ & 2 \\
\hline & & & &
\end{tabular}

Number of $(+)$ indicates the size of the C-band, $(-)$ means normal-sized band. Samples 1 and 3 had known low fertility status, whereas samples 2 and 4 had high fertility status. The relationship between average litter size and chromosome polymorphism status is indicated.

The chromosome studies were made according to a routine procedure (Christensen and Smedegård, 1978). The acrocentric chromosomes 16 and 17 were classified for polymorphism at the centromere bands as follows: the size of a band was evaluated and scored as very large $(++)$, large $(+)$ or normal $(-)$. The genotype used was $++/-$ for large differences between the $C$-bands of a pair of chromosomes; $+/-$ was correspondingly used for small differences, and $++/++,+/+$ or $-/-$ was used when both chromosomes had $\mathrm{C}$-bands of the same size. The first analysis of the centromere bands was made on $\mathrm{R}$-banded chromosomes, as it is our routine procedure. The assessment was verified on conventional C-banded preparations. 


\section{RESULTS}

The average number of ejaculates used per boar was 3.2 and $91 \%$ of the semen doses were used within $24 \mathrm{~h}$ after collection, $6 \%$ on the second day, and $3 \%$ on the third day. 239 different herds were included, and 1760 farrowings were recorded. All sows were crossbred Landrace $\times$ Yorkshire.

Due to the management practice at the AI stations, the chromosome investigations had to be carried out on boars having litter sizes closer to the average than wanted.

The individual results are shown in table I. In sample 1 (low-fertility boars), there were great differences in the sizes of the centromere bands (C-band polymorphism) on either chromosome 16 or 17 in 5 out of the 6 boars. In the second sample (high-fertility boars), only one boar exhibited chromosome C-band polymorphism. Samples 3 and 4 did not reveal such strong differences between the high- and the low-fertility groups as those found in the first two samples: only two boars in sample 3 had the genotype $++/-$. This might be due to the fact that these animals deviated much less from the mean fertility than the first two samples, as they were collected at a later time from the same population of boars.

The boars presented in table I are sorted according to average litter size. There was clearly more polymorphism in the boars with the lower litter size. A $\chi^{2}$ test for effect of the polymorphism on either chromosome 16 or 17 was made after dividing the material into two groups below or above the mean litter size of 11.61 . The effect of the chromosome polymorphism was statistically significant $\left(\chi^{2}=7.79, d f=1\right.$; $P<0.01)$.

\section{DISCUSSION}

The frequency of C-band polymorphism should be evaluated keeping in mind that the first 6 boars (sample 1) were investigated due to low litter sizes. As there were no severe chromosome anomalies, other minor conditions, that might explain the lower litter size, were investigated at the chromosome level. The frequency of chromosome C-band polymorphism in the high-fertility group is in accordance with earlier studies (Christensen and Smedegård, 1978, 1979) but the low-fertility group had a much higher frequency. This could indicate that there may be some causal relationship.

The differences in the sizes of the C-bands in the material studied are very big, so it might cause non-disjunction of the chromosomes at meiosis and then cause higher embryonic mortality in litters sired by polymorphic boars. In man, many of the chromosomes have polymorphic C-bands. An investigation by Wevrick and Huntington (1989) showed that the human C-bands are stable units with a low frequency of recombination. They concluded that unequal crossover within the repetitive $\mathrm{C}$-band DNA is a rare event. The $\mathrm{C}$-band polymorphism in man is not known to cause lowered fertility.

More studies are required to confirm our findings before practical use in swine breeding can be considered. The possibility of using genetic marker selection for improving litter size would be welcomed, as all selection programs for larger litter size in swine to date have failed to give any results (Haley et al, 1988). 
More details on this investigation will be given in a future publication (Christensen and Petersen, submitted).

\section{ACKNOWLEDGMENTS}

Inger Hvidfeldt Christensen very skillfully prepared the chromosome samples and the photos. The work has been supported by the Danish Agricultural and Veterinary Research Council grant no 17.4.3.06 and by the Animal Biotechnology Center, The Royal Veterinary and Agricultural University, Copenhagen.

\section{REFERENCES}

Christensen K, Smedegård K (1978) Chromosome markers in domestic pigs. C-band polymorphism. Hereditas 88, 269-272

Christensen K, Smedegård K (1979) Chromosome markers in domestic pigs. A new C-band polymorphism. Hereditas $90,303-304$

Gustavsson I (1988) Reciprocal translocation in four boars producing decreased litter size. Hereditas 109, 159-168

Haley CS, Avalos E, Smith C (1988) Selecting for litter size in pigs. Anim Breed Abstr 56, 317-332

Nielsen HE (1969) Growth rate, fertility and longevity of boars on different diets during rearing, and some results concerning fertility in sows. Beret Forsoegslab Statens Husdyrbrugsudvalg, 375

Wevrick R, Huntington FW (1989). Long-range organization of tandem arrays of alphasatellite DNA at the centromeres of human chromosomes: high-frequency array-length polymorphism and meiotic stability. Proc Natl Acad Sci USA 86, 9394-9398 